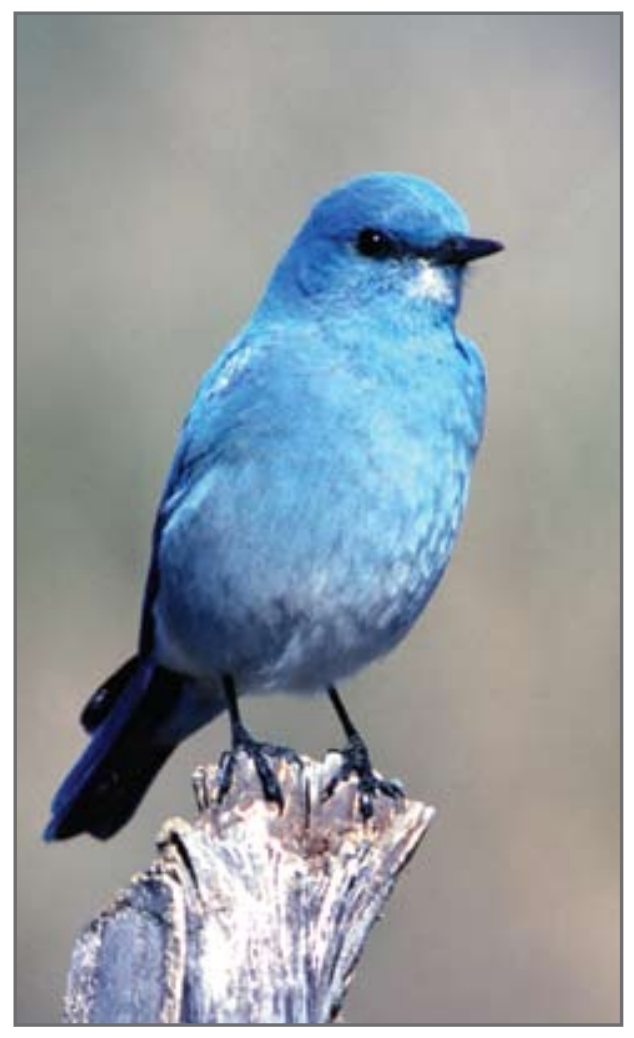

A male mountain bluebird. Photo credit: Lorne Scott

\section{MY LIFE WITH BLUEBIRDS}

\section{Lorne Scott}

Box 995, Indian Head, SK SOG 2K0 lorne.scott@sasktel.net

I was born in Indian Head, Saskatchewan and raised on a mixed farm south of town in the Aspen Parkland region of the province.

When my grandparents settled on the farm 100 years ago in 1915, the aspen bluffs were much smaller in size and maturity, as frequent prairie fires prevented the trees from getting well established. However, with settlement and cultivation, widespread grass fires were greatly reduced, allowing the aspens, willows and other shrubs to become established and reach maturity within a few decades. Aspen poplar, sometimes called "the walking tree," spread by new saplings growing up and out from the existing bluff. The ability for aspens to spread is clearly evident where whole parcels of land that have never been broke are now pretty well covered by an aspen forest.

Fifty years ago and beyond, farming was much more in harmony with nature. The aspen bluffs, shrubs, wetlands and fragmented remains of native grass interspersed by cultivated fields provided a rich and diverse landscape. The existing bluffs and wetlands were left untouched as open grassy areas were plowed for the growing of crops. Bluffs provided fire wood and fence posts, and the sloughs (wetlands) provided hay for winter feed and grazing, as did the remaining patches of grasslands. Winter brought daily chores and the harvesting of furs such as weasel, muskrat, rabbit and coyote.

Each season brought its own sights and sounds on the farm. Spring saw the return of many birds, some of which stayed to nest. Summer brought an array of wild flowers, such as cowslips (Hoary Pucoons) growing along well-worn paths followed by the cows coming home for the twice-daily milking. Fall was harvest time for garden produce, field crops and wild game.

Historically, both eastern bluebirds (Sialia sialis) and mountain bluebirds (S. currucoides) were relatively uncommon at Indian Head and in the vicinity of the Qu'Appelle Valley. The lack of nesting sites available prior to 1940 no doubt limited their numbers. In Manley Callin's book, Birds of the Qu'Appelle 1857 - 1979, observations of both bluebird species are documented as rare, irregular and a relative new comer prior to 1940.

The early homesteads and equipment often contained nooks and crannies suitable for bluebird nesting sites, and it was considered a good omen to have bluebirds nesting close to one's home. Perhaps the most frequently used bluebird nesting site was the twine box on the old binder used for cutting sheaves. By 1950 , the arrival of non-native and aggressive house sparrows and European starlings began to take over bluebird nesting sites. Remaining bluebirds were driven away from farm yards, and nested in woodpecker holes and rotted aspen snags.

My first recollection of bluebirds was around 1960, before I kept records. A pair of mountain bluebirds was nesting in the twine box on the binder, and as I went near their nest, they would dive bomb me in an attempt to scare me away and it worked. My first recorded observation of mountain bluebirds was on April 11, 1963. Since then, I have recorded the spring arrival dates of the first bluebirds each year. The earliest spring arrival was February 22, 2000. A lone male was seen by my Uncle Hartley Scott and friend, Cliff Kenney, on the outskirts of Indian Head. I saw my first single male on March 4 that year. The latest arrival date documented was April 13, 1975.

It was recognized that bluebirds would use nesting boxes, and over the years people across North America built tens of thousands of boxes for all three species of bluebirds. Dr. T.E. Musselman of Illinois is credited as being the first person to set out a number of nest boxes along a country road side. Thus, in 1934, the concept of a "Bluebird Trail" was established.

In Canada, John and Nora Lane at Brandon, Manitoba formed the Brandon Junior Birders in 1959 and subsequently set out thousands of bluebird nest boxes. Over the next few decades eastern, mountain and western bluebirds (S. mexicana) all benefited from the efforts of dedicated individuals and organizations. Bluebird numbers increased substantially in those 


\section{Number of mountain bluebirds, eastern bluebirds and tree swallows banded from 1969 to 2015.}

\begin{tabular}{|c|c|c|c|}
\hline YEAR & $\begin{array}{l}\text { MOUNTAIN } \\
\text { BLUEBIRDS }\end{array}$ & $\begin{array}{l}\text { EASTERN } \\
\text { BLUBIRDS }\end{array}$ & $\begin{array}{c}\text { TREE } \\
\text { SWALLOWS }\end{array}$ \\
\hline 1969 & 395 & 5 & 600 \\
\hline 1970 & 601 & & 849 \\
\hline 1971 & 700 & & 1450 \\
\hline 1972 & 684 & & 1396 \\
\hline 1973 & 682 & 15 & 1794 \\
\hline 1974 & 900 & & 1698 \\
\hline 1975 & 792 & 7 & 2299 \\
\hline 1976 & 169 & & 2 \\
\hline 1977 & 243 & 5 & 179 \\
\hline 1978 & 262 & & 515 \\
\hline 1979 & 136 & & 300 \\
\hline 1980 & 147 & & 38 \\
\hline 1981 & 189 & & 4 \\
\hline 1982 & & & \\
\hline 1983 & & & \\
\hline 1984 & & & \\
\hline 1985 & 76 & & 152 \\
\hline 1986 & 48 & 4 & 144 \\
\hline 1987 & 23 & & 166 \\
\hline 1988 & 166 & 9 & 70 \\
\hline 1989 & 126 & 5 & \\
\hline 1990 & 179 & & \\
\hline 1991 & 192 & 4 & \\
\hline 1992 & 116 & 4 & \\
\hline 1993 & 194 & & 9 \\
\hline 1994 & 190 & & 77 \\
\hline 1995 & 152 & 2 & 78 \\
\hline 1996 & 73 & & 117 \\
\hline 1997 & 43 & & 147 \\
\hline 1998 & 94 & 6 & 36 \\
\hline 1999 & 54 & & 89 \\
\hline 2000 & 131 & 4 & 178 \\
\hline 2001 & 26 & & 235 \\
\hline 2002 & 40 & & 124 \\
\hline 2003 & 39 & & 212 \\
\hline 2004 & 51 & & 137 \\
\hline 2005 & 16 & & 188 \\
\hline 2006 & 110 & & 181 \\
\hline 2007 & 76 & & 176 \\
\hline 2008 & 62 & & 138 \\
\hline 2009 & 32 & & 183 \\
\hline 2010 & 10 & & 209 \\
\hline 2011 & 6 & & 216 \\
\hline 2012 & 9 & & 208 \\
\hline 2013 & 3 & & 259 \\
\hline 2014 & 6 & & 310 \\
\hline 2015 & & & 322 \\
\hline TOTAL & 8,243 & 70 & 15,545 \\
\hline
\end{tabular}

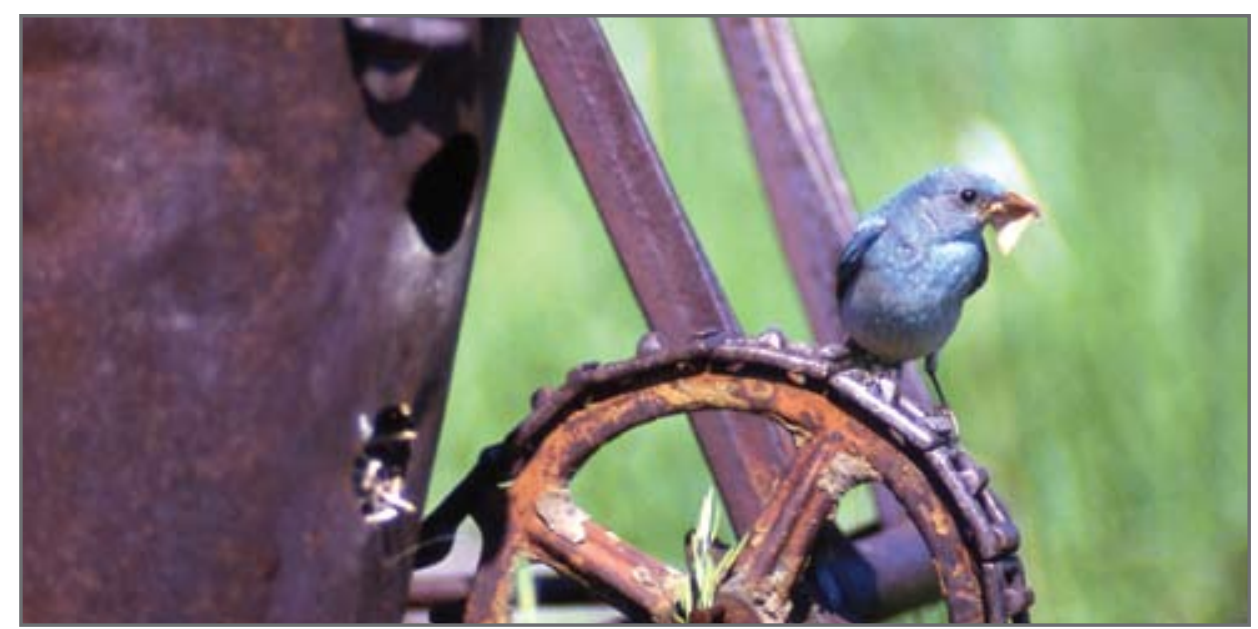

Male mountain bluebird bringing food to young in a twine box on an old binder. Photo credit: Myrna Pearman

areas where bluebird trails were established across North America.

I made my first nest box in 1963 at the age of 15 . My first boxes were placed around the farm yard and I was quite happy to have house sparrows occupy them. As I recall, the sparrow population was higher back then than it is today.

In 1965, I placed some boxes along fence lines out in the fields away from the yard. May 24, 1965 was one of the most thrilling days of my life when I discovered a pair of mountain bluebirds using one of my nest boxes. The excitement was short-lived as a few days later, a road construction crew removed the post and box and left them laying on the ground. A second pair of mountain bluebirds was discovered in a box on June 21 , but a domestic cat destroyed the nest and young. At last, on July 10, a pair of bluebirds raised five young in a third box. I also found two pairs of bluebirds nesting in old woodpecker holes in aspen trees that summer.

An additional 60 nest boxes, mostly made from hollow trees, were set out in 1966 along road sides and neighbours' fence lines. Six pairs of mountain bluebirds and two pairs of eastern bluebirds successfully nested. I had access to scrap lumber from a construction site and had some 200 nest boxes ready to set out in the spring of 1967. At least 19 pairs of mountain bluebirds nested in them.

On May 1, 1967, I began to work at the Saskatchewan Museum of Natural History (Royal Saskatchewan Museum). The following winter, I was given permission to use the carpenter shop at the Museum after hours to build nest boxes, if I supplied the lumber. About 200 nest boxes were ready to set out in the spring. I joined my bluebird trail at Broadview, Saskatchewan where it connected with John Lane's trail from Brandon, Manitoba. At least 50 pairs of mountain bluebirds nested in my boxes in 1968

In 1969, I had obtained my own federal Bird Banding Permit, thanks to the references from renowned bird bander, Dr. Stuart Houston, and long-time naturalist and Western Producer columnist, Doug Gilroy. More than 100 pairs of mountain bluebirds and two pairs of eastern bluebirds nested that year, with 395 mountain and five eastern bluebirds being banded.

On April 5 of the following year, I joined my bluebird trail at Raymore, Saskatchewan, with the Saskatoon Junior Naturalists' trail led by Stuart and Mary Houston. This addition completed the longest bluebird trail in the world, with John and Nora Lane's trail based in Brandon extending from near Winnipeg, 
west to Broadview, and my trail joining their trail at Broadview and extending west to Raymore, where it linked up with the Saskatoon Junior Naturalists' trail. The Junior Naturalists' trail extended westward from Saskatoon towards North Battleford, Saskatchewan.

During the 1970s, which was the peak operation of this longest bluebird trail in the world, thousands of nest boxes were spread over many hundreds of miles. It is estimated that 5,000 mountain bluebirds and 10,000 tree swallows fledged each year from this trail. For various reasons, the trail eventually fell into disrepair and no longer exists as it once did. However, many other individuals picked up the challenge and have placed thousands of nest boxes throughout Saskatchewan and the prairie provinces in an effort to assist bluebirds.

By 1975 , I had made and placed some 2,000 nest boxes along many miles of road. I would check all the boxes four times a year, each trip covering 800 kilometres (500 miles) and taking four days to complete. The first trip was to record and band nesting bluebird females. On the second trip, young bluebirds and nesting adult female tree swallows were banded. Trip number three was to band young Tree Swallows. A final trip in the fall was made to clean out the boxes.

Big changes occurred in 1976, when I opted to move to my uncle and aunt's farm to do my own
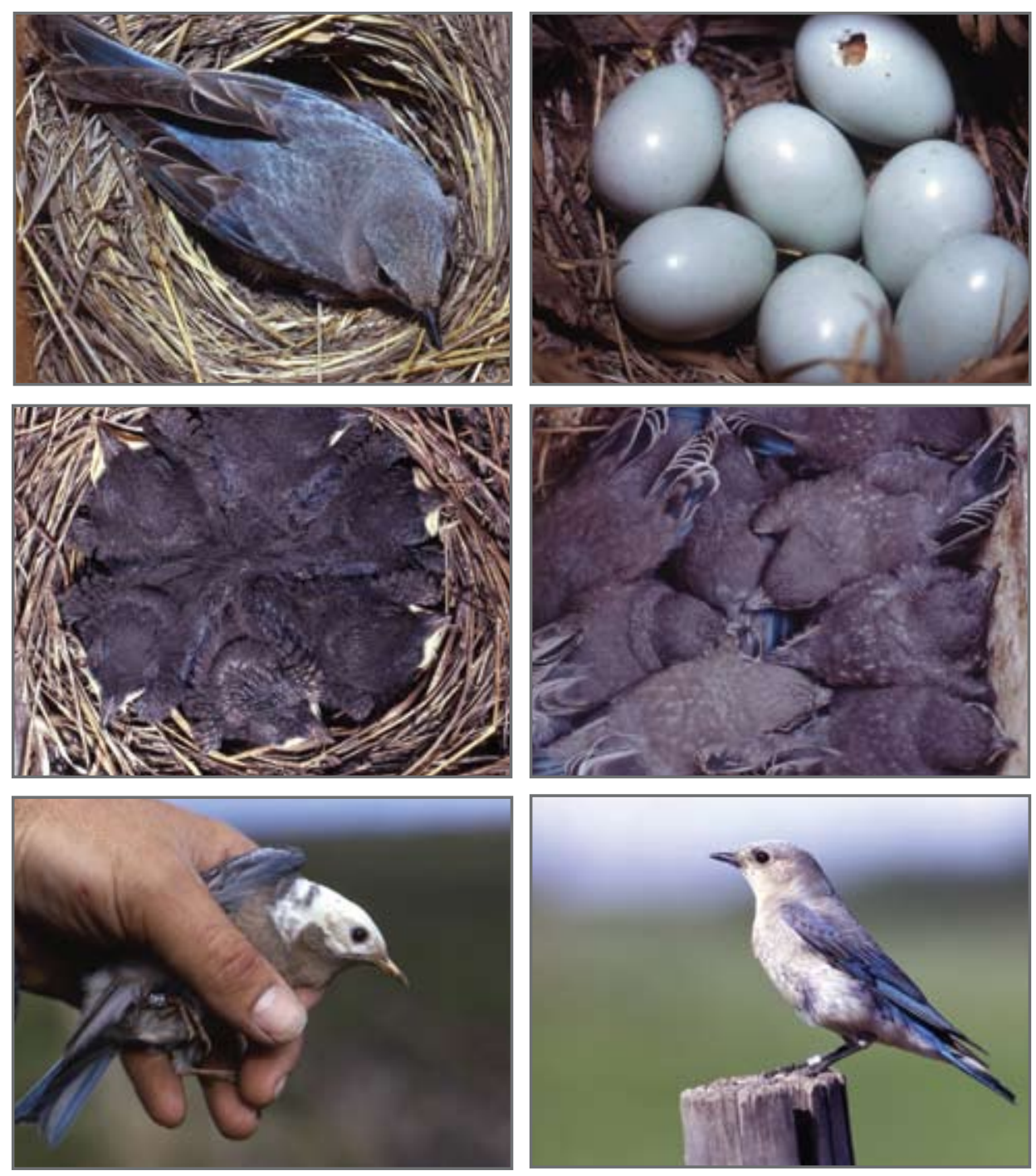

All photos: Lorne Scott

farming along with continued employment as the Park Naturalist at Wascana Centre Authority in Regina, which made for a 160-kilometre round-trip daily commute. I also got married that year. Needless to say, priorities dictated that I would not be able to maintain all my nest boxes. Fortunately, volunteers monitored and maintained portions of my trail and added their own nest boxes.

By the late 1970s, changes were evident on the landscape as aspen bluffs and natural grasslands were being increasingly cleared and plowed under. Raccoons had arrived and became a new predator that bluebirds and trail operators had to contend with. I found that in the early 1980s, these intelligent animals

\begin{tabular}{|c|c|c|c|c|c|c|c|c|c|c|c|c|c|c|c|c|c|}
\hline & & & 1970 & March & 27 & 1980 & March & 25 & 1990 & March & 3 & 2000 & February & 22 & 2010 & March & 13 \\
\hline & & & 1971 & March & 13 & 1981 & March & 3 & 1991 & March & 19 & 2001 & March & 17 & 2011 & March & 18 \\
\hline & & & 1972 & March & 11 & 1982 & March & 16 & 1992 & March & 12 & 2002 & March & 30 & 2012 & March & 10 \\
\hline 1963 & April & 11 & 1973 & March & 4 & 1983 & March & 29 & 1993 & March & 22 & 2003 & March & 29 & 2013 & March & 29 \\
\hline 1964 & April & 1 & 1974 & April & 9 & 1984 & March & 26 & 1994 & March & 13 & 2004 & March & 23 & 2014 & April & 5 \\
\hline 1965 & April & 8 & 1975 & April & 13 & 1985 & March & 14 & 1995 & March & 14 & 2005 & March & 27 & 2015 & March & 30 \\
\hline 1966 & March & 12 & 1976 & March & 22 & 1986 & March & 13 & 1996 & April & 8 & 2006 & March & 28 & & & \\
\hline 1967 & March & 23 & 1977 & March & 17 & 1987 & March & 27 & 1997 & March & 22 & 2007 & March & 11 & & & \\
\hline 1968 & March & 5 & 1978 & March & 25 & 1988 & March & 2 & 1998 & March & 25 & 2008 & March & 16 & & & \\
\hline 1969 & March & 23 & 1979 & March & 16 & 1989 & March & 25 & 1999 & March & 14 & 2009 & March & 20 & & & \\
\hline
\end{tabular}


would sometimes retrace my steps to each nest box where they would feed on nesting females, eggs and young. Because of their predation, I chose not to visit or band any bluebirds or swallows between 1982 and 1984 .

In an attempt to reduce raccoon predation, boxes are now retrofitted with a wire mesh raccoon guard around the entrance. The guards work with some success. These strong predators are sometimes able to rip apart older nest boxes in order to get at the contents inside.

Over the past 30 years, I have continued to maintain, monitor and band birds in boxes around the farm and nearby areas. A friend also maintains a short trail nearby where we continue to band bluebirds. Unfortunately, the number of mountain bluebirds nesting on the farm has declined over the past 20 years. This decline is puzzling, because my farm is one of the few places where the natural landscape has been preserved and the number of available nest boxes has actually increased. It appears to me that the bluebirds are simply not returning in the spring.

During the peak years in the 1970s, 25 to 30 pairs of mountain bluebirds nested on the farm each year, and the numbers were still fairly good in the 1980s. However, there was evidence of decline in the 1990s. The following information is a sobering reality: In 2008, 10 pairs nested on the farm. In 2009, six pairs nested. Only three pairs nested in 2010. Two pairs nested in 2011 and again in 2012. One pair fledged three young in 2013. One pair nested in 2014 and a raccoon ripped open the nest box devouring the young. For the first time in 50 years, no bluebirds nested on the farm in 2015.

The numbers of mountain bluebirds observed in the spring has also declined significantly. In 2015,

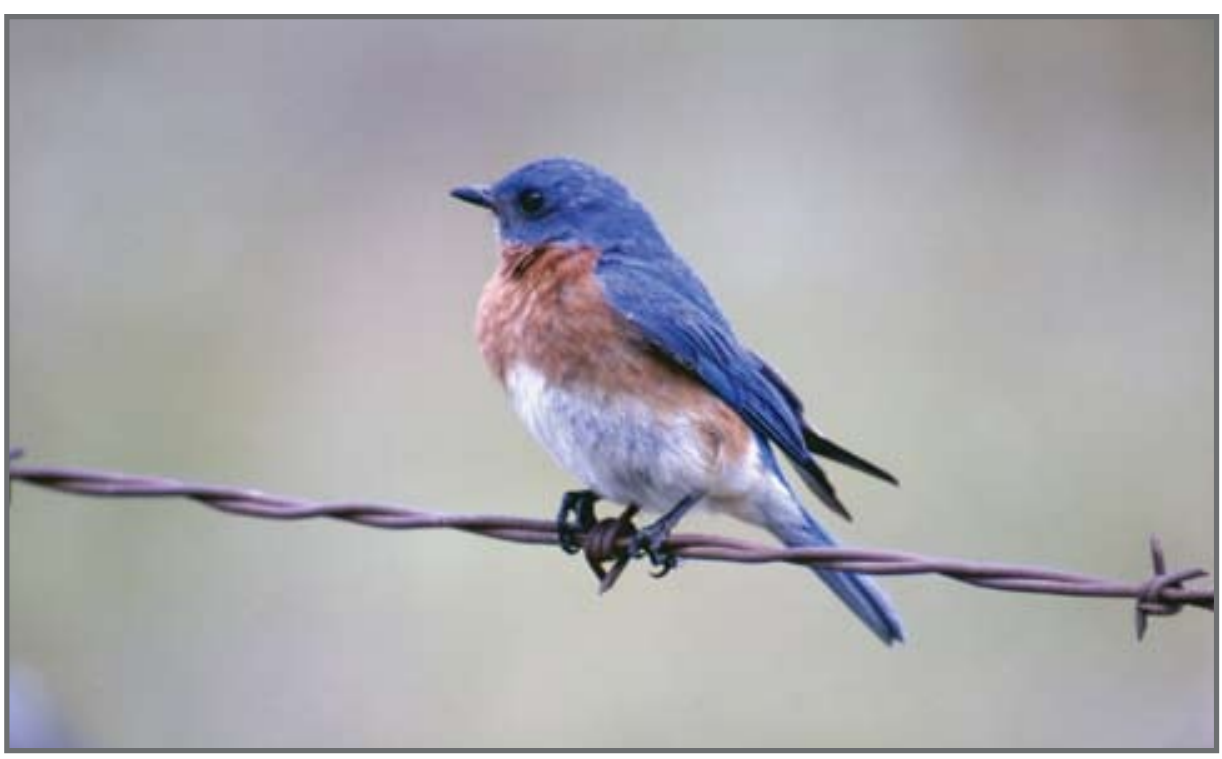

Male eastern bluebird. Photo credit: Fred Lahrman
I visited familiar bluebird migration haunts several times looking for these harbingers of spring. I finally saw a lone female on March 30 and a lone male later in April.

Other bluebird trail operators in Saskatchewan have also noted a big decline in the number of nesting bluebirds. Myrna Pearman at the Ellis Bird Farm near Red Deer, Alberta has also noted a significant decline in nesting mountain bluebirds in the area northeast of Red Deer. Ironically, they seem to have increased in other local areas, such as the Lousana area southeast of Red Deer. The cause of the decline is likely due to a number of factors including late spring snow storms, habitat loss and food supply.

Each year I set out a few more nest boxes on the farm and the natural habitat will be protected in perpetuity through a Conservation Easement with the Saskatchewan Wildlife Federation. I will eagerly be looking for the first bluebirds arriving on a mild south breeze in March. Maybe a few will return to nest?

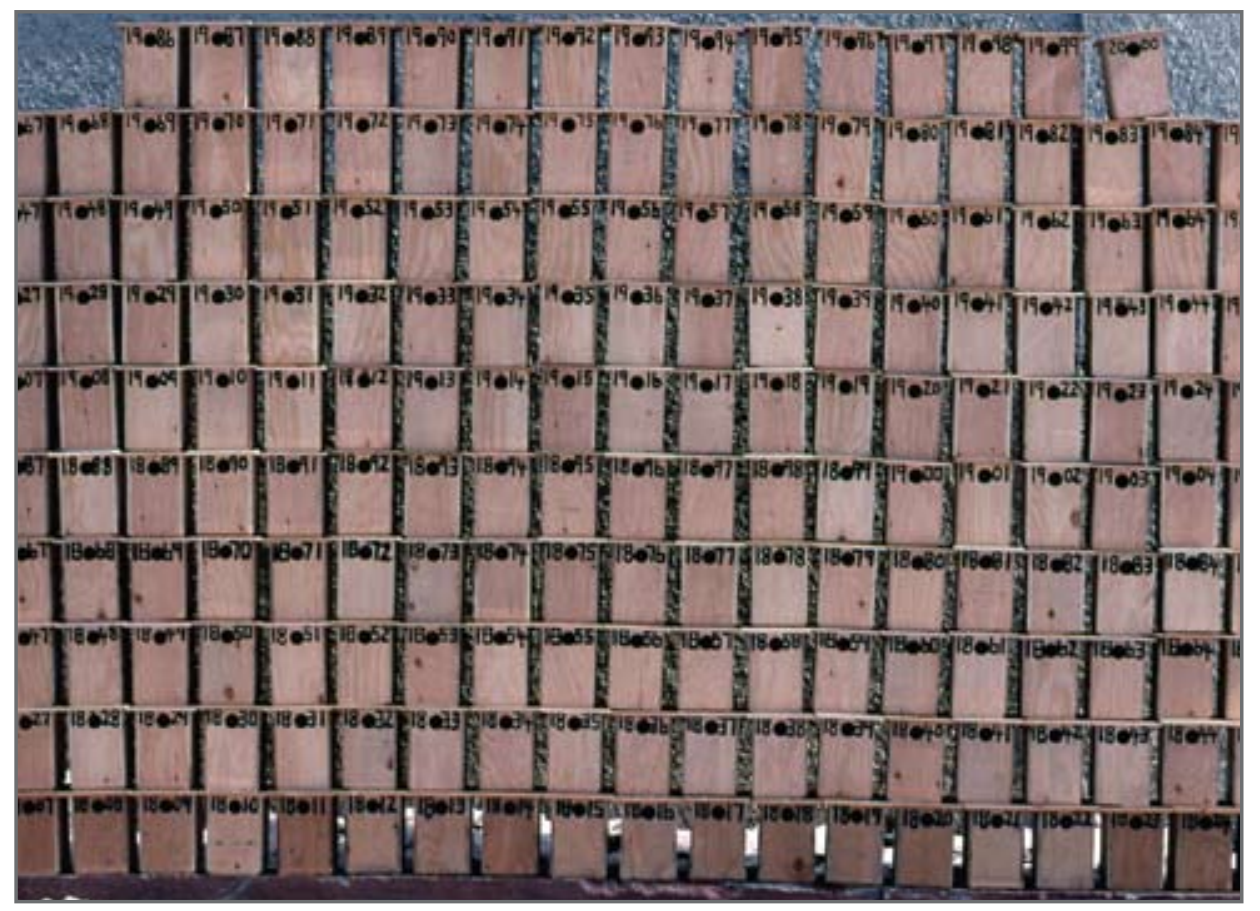

Some 200 nest boxes built over winter and ready to set out in early spring. Photo credit: Lorne Scott 